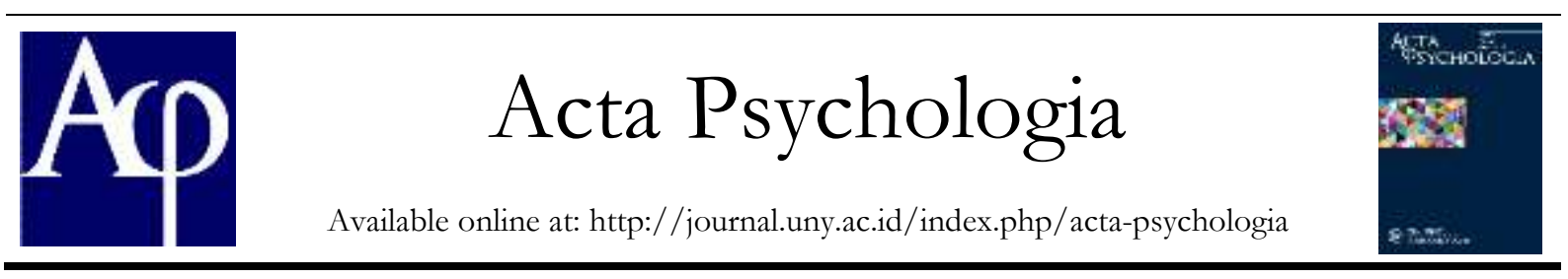

\title{
Transmisi Nilai Orang Tua Berbeda Agama pada Anak
}

\author{
Evangelista Christiani \\ Jurusan Psikologi, Fakultas Ilmu Pendidikan, Universitas Negeri Yogyakarta; \\ Jl. Colombo No. 1 Sleman Yogyakarta, 55281 \\ christianieva@yahoo.com
}

\begin{abstract}
Abstrak
Penelitian ini bertujuan untuk mengetahui nilai-nilai apa saja yang ditansmisikan, proses transmisi nilai dalam keluarga beda agama, dan hambatan apa saja yang muncul pada anak dari keluarga berbeda agama. Penelitian ini menggunakan metode kualitatif dengan pendekatan fenomenologis. Penelitian ini menunjukkan nilai-nilai yang ditransmisikan keluarga beda agama adalah nilai religiusitas, toleransi, bersyukur, kesederhanaan, dan menghargai. Selain itu ada nilai lain seperti memiliki pendirian, kekeluargaan, tanggung jawab, bekerja keras, dan sopan santun dalam bermasyarakat. Proses transmisi nilai yang terjadi dalam keluarga adalah mengajarkan nilai dengan menyampaikan dan menanamkan nilai, mencontohkan nilai, dan membimbing yang terdiri dari menegur, memberikan motivasi dan terus membina anak dengan ikut andil dalam kegiatan anak ketika mengaplikasikan nilai. Serta hambatan yang muncul pada anak adalah konflik dengan pikirannya sendiri.
\end{abstract}

Kata Kunci: transmisi nilai, keluarga beda agama

\begin{abstract}
This study aimed to discover what values that parents transmited, the process of transmitting values in multi-religion families, and what obstacles appeared in children from the multi-religion family. This study used qualitative methods with a phenomenological approach. This study showed that the values transmitted by multi-religion families were the values of religiosity, tolerance, gratitude, simplicity, and respect. Apart from that, there were other values such as assertiveness, family, responsibility, hard work, and manners. The process of value transmission that occured in the family are teaching value by communicating and embedding values, exemplifying values, and guiding which consists of reprimanding, motivating, and keep fostering the children by participating in children's value-related activities. Also, the obstacles that appeared in children are conflicts with their own thoughts.
\end{abstract}

Keywords: transmission of value, multi-religion family.

\section{Pendahuluan}

Nilai adalah dasar penting untuk pembentukan kepribadian manusia dalam kehidupannya. Steeman mengemukakan nilai adalah sesuatu yang memberi makna pada hidup, serta turut andil pada titik tolak, isi, dantujan hidup (Sjarkawi, 2008). Bagaimana caramembentuk dan mempertahankan nilai yang baik dalam kehidupan selalu menjadi topik yang menarik untuk dibahas karena nilai bukan hanya sebuah keyakinan, tetapi juga menyangkut tindakan sebagai tolak ukur dari tindakan yangdilakukan oleh seseorang
(Auliarahma, 2015).

Devito mengutarakan bahwa salah satu sumber dari pembentukan nilai adalah keluarga. Keluarga adalah tempat belajar pertama bagi anak dengan berbagai fungsi yang dijalankan, salah satu di antaranya adalah fungsi sosialisasi, yaitu bagaimana orang tua mempersiapkan bekal selengkap mungkin kepada anak dengan cara memperkenalkan pola tingkah laku, sikap keyakinan, cita-cita, dan nilai-nilai yang dianut oleh masyarakat serta mempelajari peranan yang diharapkan akan dijalankan oleh mereka (Rosmawaty, 2010). 
Fungsi sosialisasi dalam keluarga berarti melakukan proses pembelajaran terhadap seorang anak. Dalam proses ini kedua orang tuaberkewajiban membantu, merawat, membimbing dan mengarahkan anak-anak yang belum dewasa di lingkungannya dalam pertumbuhan dan perkembangan untuk mencapai kedewasaan masing-masing dan dapat membentuk kepribadiannya (Amir \& Trianasari, 2013).

Orang tua yang dapat memberi ajaran nilai yang sesuai dengan anak akan menghasilkankesamaan pandangan tentang nilai sehingga anak lebih mudah untuk menerima dan menerapkan nilai. Selain itu, keberhasilantransmisi nilai dapat ditunjukkan dengan dengan tingkah laku dan kepribadian anak yang baik, halini akan menimbulkan rasa bangga pada orangtua karena berhasil membuat anak menerapkannilai yang baik (Seligman, 2000). Hal ini dinamakan sebagai proses transmisi nilai.

Transmisi nilai adalah ketika orang tua berusaha memberi pemahaman tentang nilai yang dianut oleh mereka agar dapat dijadikan sebagai pedoman hidup anak (Knafo \& Schwartz, 2009). Dalam transmisi nilai tercakup enkulturasi yaitu proses penyerapan norma dan nilai secara tak langsung melalui paparan dan observasi, serta sosialisasi yang merujuk pada proses pengajaran yang dilakukan secara sengaja dengan pengawasan pada individu (Lestari, 2014).

Fakta yang terjadi di lapangan menunjukkan tidak semua keluarga dapat mentransmisikan nilai dengan maksimal pada anak, hal ini dapat menyebabkan tdiak adanya kesamaan pandangan nilai antara anak dan orang tua kedepannya. Kondisi ini dapatmenyulitkan proses koordinasi antar generasi tentang nilai-nilai yang dianut orang tua ke anak (Selignman, 2000). Selain itu, anak juga dapat mengalami keraguan dengan transmisi nilai orang tuanya (Barni, 2011) serta kemungkinan tidak menetapnya transmisi nilai pada anak (Min, 2012).

Dampak lain yang dapat terjadi adalah memudarnya nilai-nilai yang dulunya dipegang teguh sebagai pedoman hidup anak, hal ini terbukti dengan semakin banyak pelajar yang terlibat dalam konflik sosial masyarakat seperti tawuran, geng motor, dan tindak kekerasan lainnya. Hidup di tengah perbedaan akan menyulitkan individu yang tidak mampu menerima dan menghargai perbedaan yang ada di masyarakat (Sari, 2014).

Terdapat berbagai faktor yang menyebabkan kurang maksimalnya transmisi nilai, salah satu faktor tersebut adalah perbedaan agama orang tua, hal ini menandakan orang tua tidak terlalu religious (Storm \& Voas, 2012). Data yang didapat dari Yayasan Harmoni Mitra Madania menyebutkan selama kurun waktu sejak tahun 2004 hingga 2012 tercatat 282 pasangan berbeda agama di Indonesia yang melaksanakan perkawinan beda agama.

Penelitian ini memfokuskan bagaimana transmisi nilai orang tua yang berbeda agama pada anak. Penelitian ini menarik dan penting untuk dilakukan dikarenakan transmisi nilai yangditeliti adalah transmisi nilai pada orang tua yangmemiliki perbedaan agama. Di Indonesia sendiri kebanyakan perkawinan berbeda agama masih mengalami masalah-masalah khusus baik dari dalam keluarga yaitu dari orang tua ke orang tua dan orang tua ke anak, maupun masalah- masalah yang melibatkan orangorang di sekitar pasangan tersebut.

Berdasarkan uraian di atas, maka tujuan dari penelitian ini adalah mengetahui nilai-nilai apa yang ditransmisikan, bagaimana proses transmisi nilai orang tua berbeda agama pada anak dan hambatan apa yang dialami anak dalam proses transmisi nilai orang tua berbeda agama. Adapun manfaat dari penelitian ini adalah memperkaya ilmu psikologi sosial dan psikologi keluarga utamanya pada transmisi nilai orang tuaberbeda agama pada anak baik untuk keluarga.

\section{Metode Penelitian}

\section{Jenis Penelitian}

Penelitian ini merupakan penelitian kualitatif dengan pendekatan fenomenologi. 


\section{Waktu dan Tempat Penelitian}

Penelitian ini dilaksanakan di Yogyakartadan Semarang. Waktu penulisan penelitian dilakukan mulai tanggal 22 Oktober 2018 sampai tanggal 18 Maret 2019.

\section{Subjek Penelitian}

Subjek penelitian ini adalah keluarga yang orang tuanya (suami istri) memiliki perbedaan agama beserta anak mereka yang tinggal di Jogjakarta dan atau Semarang, subjek didapatkan dengan teknik sampling purposive

\section{Prosedur}

Penelitian ini terdiri dari beberapa tahap. Tahap pertama adalah memperkenalan diri dan menginformasikan tujuan penelitian kepada 2 keluarga yang menjadi subjek penelitian. Tahap kedua adalah melakukan wawancara mendalam. Wawancara dilakukan dengan menggunakan pedoman wawancara yang telah disiapkan. Tahap selanjutnya peneliti melakukan probing dan triangulasi data pada subjek.

\section{Data, Instrumen, dan Pengumpulan Data}

Data diperoleh langsung dari subjek penelitian. Data tersebut diperoleh melalui wawancara mendalam kepada ayah, ibu, dan anak dari dua keluarga berbeda agama di Yogyakarta dan Semarang. Adapun instrumen yang digunakan adalah peneliti, pedoman wawancara, dan perekam suara. Masingmasing subjek diwawancara kurang lebih dua kali untuk mendapatkan informasi yang selengkap- lengkapnya.

\section{Teknik. Analisis Data}

Teknik analisis data yang digunakan dalam penelitian ini adalah Interpretative Phenomenological Analysis (IPA). Interpretative Phenomenological Analysis (IPA) adalah pendekatan kualitatif yang bertujuan untuk memberikan pemeriksaan rinci terhadap pengalaman hidup subjek yang diteliti (Smith dkk., 2009).

\section{Hasil Penelitian dan Pembahasan}

Nilai yang Ditransmisi

Tabel 1. Nilai yang Ditransmisi

\begin{tabular}{ll}
\hline \multicolumn{1}{c}{ Keluarga 1 } & \multicolumn{1}{c}{ Keluarga 2 } \\
\hline Religiusitas & Toleransi \\
Kekeluargaan & Sosial \\
Kesederhanaan & Sopan santun \\
Kerja keras & Tanggung jawab \\
Tanggung jawab & Kerja keras \\
Kemandirian & Kebersyukuran \\
Toleransi & Keadilan \\
Kebersyukuran & Religiusitas \\
& Kejujuran \\
\hline
\end{tabular}

Berdasarkan tabel 1, nilai-nilai yang ditransmisikan oleh orang tua berbeda agama pada anaknya terdiri dari nilai religiusitas, bertanggungjawab kekeluargaan, kesederhanaan, menghargai, kerja keras, toleransi, sopan santun, sosial bermasyarakat, dan bersyukur. Nilai-nilai ini sesuai dengan nilai terminal dan nilai instrumental berdasarkan Rokeach Value Survey (Rokeach, 1973).

Definisi dari nilai terminal adalah pencapaian yang diinginkan individu (Rokeach, 1973). Nilai terminal yang muncul dari penelitian ini adalah nilai religiusitas yang meliputi toleransi, bersyukur, kesederhanaan, dan menghargai.

Nilai toleransi menjadi nilai yang penting dan utama untuk ditransmisikan dalam keluarga beda agama karena selain memiliki arti terbuka dan menerima keindahan perbedaan yaitu perbedaan agama orang tua dalam keluarga (Davis, 2010), toleransi juga merupakan usaha individu untuk menghargai individualitas dan perbedaan yang ada sambil mengeliminasi pemecah belah dan mengatasi ketegangan akibat kekacauan (de Muynck dkk, 2017; DiSalvo \& Copulsky, 2009; Elbasani \& Roy, 2017). 
Proses Transmisi Nilai

Tabel 2. Proses Transmisi Nilai

\begin{tabular}{ll}
\hline \multicolumn{1}{c}{ Keluarga 1 } & \multicolumn{1}{c}{ Keluarga 2 } \\
\hline $\begin{array}{l}\text { Membuat } \\
\text { kesepakatan tentang } \\
\text { agama anak }\end{array}$ & $\begin{array}{l}\text { Membuat } \\
\text { kesepakatan tentang } \\
\text { agama anak }\end{array}$ \\
\hline $\begin{array}{l}\text { Mengajarkan nilai } \\
\text { dengan komunikasi } \\
\text { sehari-hari }\end{array}$ & $\begin{array}{l}\text { Mengajarkan disertai } \\
\text { dengan ekspresi } \\
\text { wajah }\end{array}$ \\
\hline $\begin{array}{l}\text { Mencontohkan dalam } \\
\text { nilai-nilai }\end{array}$ & $\begin{array}{l}\text { Mencontohkan nilai } \\
\text { dalam kehidupan } \\
\text { kehidupan sehari- } \\
\text { hari sehari-hari }\end{array}$ \\
\hline $\begin{array}{l}\text { Membimbing } \\
\text { dengan memberi } \\
\text { tahu ketika anak } \\
\text { salah }\end{array}$ & $\begin{array}{l}\text { Membimbing dengan } \\
\text { memberi tan tahu } \\
\text { memotivasi anak }\end{array}$ \\
& $\begin{array}{l}\text { serta ikut andil dalam } \\
\text { penerapan nilai yang } \\
\text { dilakukan anak }\end{array}$ \\
& $\begin{array}{l}\text { Membuatkesepakatan } \\
\text { tentang nilai yang } \\
\text { ditransmisikan }\end{array}$ \\
\hline
\end{tabular}

Dari hasil wawancara, tampak dua keluarga yang menjadi responden terlihat peran positif orang tua dalam proses transmisi nilai kepada anak. Orang tua dalam pada keluarga menyadari bahwa dalam keluarga ada banyak fungsi yang dijalankan (Friedmen, 2010).

Responden orang tua menyadari ada kemungkinan perbedaan nilai yang akan mereka transmisikan pada anak karena perbedaan agama di antara keduanya, sehingga dalam keluarga beda agama orang tua melakukan antisipasi sebelum melakukan transmisi nilai dengan membuat kesepakatan bersama yaitu jika memiliki anak, mereka akan mengikuti agama salah satu orang tuanya sampai dapat memutuskan pilihannya sendiri kelak. Hal ini dilakukan dengan harapan semakin anak menganggap bahwa ayah dan ibu mereka memiliki nilai yang sama, semakin mudah dan siap anak untuk menerima prioritas nilai dari orang tua (Chan \&Tam, 2016).

Orang tua pada pada keluarga beda agama yang menjadi responden juga bersikap demokratis, menghargai dan memahami keadaan anak dengan kelebihan kekurangannya, dari wawancara dengan responden orang tua didapatkan bahwa anak diberi kesempatan untuk mengeksplor masing-masing agama orang tuanya sebelum anak memutuskan sendiri sehingga ketika anak memutuskan mereka sudah mengetahui bagaimana ritual dan ajaran dari agama yang dipilih.

Berdasar temuan peneliti dari hasil wawancara, proses transmisi nilai pada anak dimulai dengan mengajarkan nilai yaitu orang tua menyampaikan menjelaskan tentang tujuan mereka mentransmisikan nilai dan menanamkan nilai pada anak. Pada tahap ini orang tua menggunakan metode kognitif dengan komunikasi sehari-hari dan menanamkan nilai pada anak, orang tua mengajak anak untuk memahami kejadian pada nilai-nilai dengan menggunakan bahasa penyampaian yang efektif dan memberikan penjelasan logis tentang pentingnya nilai tersebut. Proses ini menjadi efektif dalam transmisi nilai karena anak dapat memahami dan memiliki gambaran tentang nilai sejak awal proses transmisi nilai (Lestari, 2014).

Proses selanjutnya setelah anak memahami nilai yang akan ditransmisikan oleh orang tuanya adalah orang tua mencontohkan nilai atau metode sosialisasi nilai mengamati dan meniru. Pada proses ini anak diberikan contoh bagaimana implementasi dari nilai-nilai yang sudah diajarkan oleh orang tuanya dalam kehidupan sehari-hari (Lestari, 2014).

$$
\text { Orang tua mencontohkan }
$$
bagaimana perilaku saling memberi perhatian pada anggota keluarga lain seperti mengurus adik dan saling membantu ketika ada yang butuh bantuan. Proses ini efektif dalam transmisi nilai karena proses peneladanan akan lebih kuat pada yang anak menganggap ada kesamaan atribut antara mereka dengan orang tua (Barni, 2011).

Proses terakhir setelah mengajarkan dan memberi contoh secara langsung, orang tua akan membimbing anak yaitu dengan mengingatkan ketika anak melakukan 
kesalahan, memberikan motivasi, dan terus ikut andil dalam kegiatan-kegiatan implementasi nilai sampai anak dapat menerapkan nilai-nilai tersebut dalam kehidupannya. Metode afektif ini menjadi efektif dalam proses transmisi nilai karena dalam membimbing akan muncul perasaan tertentu pada anak yaitu kelekatan dari afeksi antara anak dengan orang tua sehingga menyebabkan anak lebih mudah memahami dan tertarik pada nilai-nilai yang akan ditransmisikan (Lestari, 2014).

Anak juga akan mendapat metode pengkondisian, yaitu mendapatkan hadiah jika berhasil mencapai target yang sudah disepakati bersama orang tua, atau mendapat pengukuhan sehingga hal ini memperkuat perilaku anak dari transmisi nilai orang tua (Lestari, 2014).

\section{Faketor Pendukung Transmisi Nilai}

Faktor pendukung dalam transmisi nilai yang ditemukan dalam penelitian ini dapat dilihat pada tabel 3 berikut.

\begin{tabular}{ll}
\hline \multicolumn{1}{c}{ Keluarga 1 } & \multicolumn{1}{c}{ Keluarga 2 } \\
\hline $\begin{array}{l}\text { Lingkungan yang } \\
\text { mendukung }\end{array}$ & $\begin{array}{l}\text { Anak paham } \\
\text { dengan perbedaan } \\
\text { agama orangtua }\end{array}$ \\
\hline $\begin{array}{l}\text { Anak bersekolah di } \\
\text { sekolah berbasis } \\
\text { religi }\end{array}$ & $\begin{array}{l}\text { Anak bersekolah di } \\
\text { sekolah berbasis } \\
\text { religi }\end{array}$ \\
\hline Anak dan orang tua & Anak memiliki \\
memiliki hubungan & hubungan yang \\
yang dekat & dekat dengan orang \\
& tua \\
\hline
\end{tabular}

Faktor pendukung dari dalam keluarga adalah hubungan yang baik antara orang tua dan anak yaitu orang tua dan anak dekat secara emosional baik pada keluarga satu maupun keluarga dua, meskipun sempat muncul konflik namun hal ini malah menimbulkan kedekatan yang lebih pada ibu dan anak kedua, menurut Barni (2011) kedekatan anak dengan orang tua anak dapat memotivasi anak untuk lebih menerima nilai dari orang tua.
Selain kedekatan anak dengan orang tua, orang tua pada dua keluarga beda agama ini menerapkan pola asuh autotitatif yaitu orang tua secara aktif mengarahkan dan memberi masukan yang sesuai dengan kemampuan anaknya namun tidak serta merta menentukan perilaku apa saja yang harus dilakukan anaknya (Andri, Winarti, \& Utami, 2001).

Lebih lanjut, dukungan lingkungan juga turut andil dalam pembentukan nilai. Pada keluarga satu lingkungan mendukung nilai toleransi anak karena anak tumbuh besar di kampung yang majemuk di mana jumlah pemeluk agama Islam dan Kristen hampir seimbang, acara hari besar dirayakan dengan penuh toleransi oleh semua warga sehingga anak tidak mengalami penolakan di lingkungannya dan semakin terbiasa dengan perbedaan yang ada (Chan \& Tam, 2016). Selain faktor pendukung dari lingkungan, anak juga mendapat faktor pendukung dari sekolah yang berbasis religi yang membuat mereka mendapat tambahan dan penguatan pada nilai religiusitas (Imron, 2011).

\section{Faktor Penghambat Transmisi Nilai}

Salah satu faktor penghambat yang dialami oleh keluarga dalam proses transmisi nilai adalah perbedaan kepribadian anak, hal ini menyebabkan orang tua mencari cara agar tetap dapat mentransmisikan nilai dan masing-masing anak tetap menerima serta menerapkan nilai yang ditransmisikan, hambatan ini dapat terselesaikan dengan orang tua yang melakukan pendekatan transmisi nilai sesuai dengan kepribadian masing-masing anak.

Selanjutnya terdapat hambatan karena anak memasuki usia remaja yang membuat mereka mengalami kesulitan mengontrol emosi dan cenderung berlaku sesuai keinginan mereka sehingga lebih susah dikendalikan dan meledak- ledak (Hurlock, 1980), untuk mengatasi faktor penghambat ini orang tua tetap melakukan komunikasi 
tentang nilai-nilai yang ditransmisikan dengan mencontohkan perilaku pada anak.

\section{Hambatan Pada Anak}

Berdasarkan penelitian ini ditemukan juga hambatan yang dialami anak dari keluarga beda agama, anak dari keluarga dua menyatakan dalam wawancara bahwa hambatan yang dialami ketika menerima transmisi nilai dari orang tuanya adalah dari pikiran dari dirinya sendiri yang menganggap memang mudah dilakukan menurut orang tuanya karena mereka hanya mentransmisikan namun ia tidak mengalami kebingungan tentang nilai yang ditransmisikan oleh orang tuanya.

\section{Simpulan dan Saran}

Berdasarkan hasil penelitian dan pembahasan, maka diperoleh beberapa simpulan. Simpulan-simpulan tersebut yakni nilai-nilai yang ditransmisikan dalam proses transmisi nilai dalam penelitian ini adalah nilai religiusitas yang meliputi toleransi, bersyukur, kesederhanaan, dan menghargai. Nilai lain yang muncul adalah teguh hati atau memiliki pendirian, mencintai dalam bentuk saling membantu, menyayangi dan menjaga keluarga serta orang lain, tanggung jawab, ambisius dalam bentuk bekerja keras, dan sopan santun dalam bermasyarakat. Nilai yang menjadi ciri khas dalam keluarga beda agama adalah nilai toleransi.

Selanjutnya, proses transmisi nilai yang terjadi dalam keluarga adalah mengajarkan nilai dengan menyampaikan dan menanamkan, mencontohkan, dan membimbing yang terdiri dari menegur ketika anak salah, memberikan motivasi dan terus membina anak dengan ikut andil dalam kegiatan anak ketika menerapkan nilai. Ada kesepakatan yang dibuat di awal pernikahan oleh orang tua terkait agama apa yang akan dipeluk anak.

Selain terdapat kesepakatan, orang tua melakukan kerja sama dalam transmisi nilai pada anak dengan mentransmisi nilai yang sama serta memberikan anak kesempatan untuk mempelajari agama keduanya. Kedua hal ini sekaligus menjadi perbedaan transmisi nilai dari orang tua berbeda agama dengan transmisi nilai dari orang tua yang memiliki agama sama.

Terakhir, ada konflik pada keluarga dua karena anak memutuskan untuk memilih agama ibunya di usia remaja. Pada keluarga dua, salah satu anak juga mengalami kesulitan dalam menerima transmisi nilai karena pikirannya sendiri.

\section{Saran}

1. Bagi Subjek

Subjek telah menemukan cara yang sesuai untuk mentransmisikan nilai pada anak. Meskipun demikian, subjek perlu memberi perhatian lebih pada hambatan yang dialami anak yang mengalami kesulitan menerima nilai karena pikirannya sendiri. Anak akan merasa lebih baik jika hambatan yang dialami diselesaikan Bersama dengan orang tua.

2. Bagi Pasangan Berbeda Agama yang akan menikah

Pada penelitian ini ditemukan fakta bahwa sempat muncul konflik pada salah satu keluarga karena keputusan anak untuk memilih agama ketika usianya dianggap belum dewasa untuk memutuskan oleh salah satu orang tua, sehingga penting bagi orang tua untuk membuat kesepakatan terkait agama yang akan dianut anak termasuk pada usia berapa anak dapat menentukan agamanya sendiri dan sebisa mungkin nantinya anak diberi pemahaman terkait perbedaan agama orang tuanya.

3. Bagi Peneliti Selanjutnya

Bagi peneliti selanjutnya dapat menambah jumlah subjek dengan anak berusia selain dewasa awal karena penelitian ini sudah membahas transmisi nilai pada anak di usia dewasa awal. Terakhir, peneliti selanjutnya diharapkan dapat melakukan observasi padasubjek agar mendapat hasil yang lebih 
mendetail dan maksimal.

\section{Daftar Pustaka}

Amir \& Trianasari. (2013). Pola komunikasi antarpribadi dalam pengasuhan anak: Kasus orang tua beda agama (Interpersonal communication patterns in parenting: The case of parents with different religion). Jumal Komunikasi KAREBA, 2(1)

Andri, Winarti, \& Utami. (2001). Pola asuh orangtua dan nilai-nilai kehidupan yang dimiliki oleh remaja. Fenomena: Jurnal Psikologi. Hal 71-101

Auliarahma. (2015). Hilangnya kedudukan nilai- nilai pancasila dalam kehidupan masyarakat. Tugas. STMIK AMIKOM Yogyakarta

Barni, Daniela, et al. (2011). Value transmission in the family: do adolescents accept the values their parents want to transmit? Joumal of Moral Education, 40:1, 105-121

Chan, H.-W., \& Tam, K.-P. (2016). Understanding the lack of parentchild value similarity: The role of perceived norms in value socialization in immigrant families. Journal of Cross-Cultural Psychology, 47(5), 651-669. Diambilpada 25 April 2018, https://doi.org/10.1177/002202211 6635744.

Davis, A. (2010). Defending religious pluralism for religious education. Ethicsand Education, 5 (3), 189-202.

De Muynck, B., Vos, P., Hoogland, J., \& Van der Stoep, J. (2017). A Distinctive of Christian Higher Education: Educating for Vocation. Christian Higher Education, 16 (1-2), 310.

Friedman. (2010). Keperawatan keluarga. Yogyakarta: Gosyen Publishing.
Hurlock, E. B. (1980). Psikologi perkembangan: suatu pendekatan sepanjang rentang kehidupan. Jakarta: Gramedia.

Imron, A. (2012). Proses manajemen mutu sekolah dasar berbasis relegi. Jurnal Sekolah Dasar. 21(2):27-38.

Knafo, A. \& Schwartz, S. (2009). Accounting for parent-child value congruence: theoretical considerations and empirical evidence. In U. Schönpflug (Ed.), Culture and psychology. Cultural transmission: Psychological, developmental, social, and methodological aspects (pp. 240-268). New York, NY, US: Cambridge University Press.

Lestari, Sri. (2014). Psikologi keluarga penanaman nilai dan penanganan konflik dalam keluarga. Jakarta: Kencana Prenada Media Group.

Min, J,. Silvester, M., \& Lendon,J. (2012). Intergenerational transmission of values over the family life course. Advances in Life Course Research Volume 17, Issue 3, September 2012, 112-120.

Rokeach, M. (1973). The nature of human values. New York: Free Press.

Rosmawaty. (2010). Mengenal ilmu komunikasi. Jakarta: Widya Padjadjaran

Sari, Yunu M. (2014). Pembinaan toleransi dan peduli sosial dalam upaya memantapkan watak kewarganegaraan (civic disposition) siswa. Jurnal Pendidikan Ilmu Sosial, Volume 23 No. 1, Edisi Juni 2014.

Seligman, C., Olson, J. M., \& Zanna, M. P. (Eds.). (2013). The Ontario symposium on personality and social psychology, Vol. 8. The psychology of values: The Ontario symposium, Vol. 8. Hillsdale, NJ, US: Lawrence ErlbaumAssociates, Inc.

Sjarkawi. (2008). Membentuk kepribadian anak "Peran moral intelektual, emosional, dan sosial 
sebagai mujud integritas membangun jati diri".

Jakarta: PT. Bumi Aksara.

Smith, J. A., Flowers, P., \& Larkin, M.

(2009). Interpretative Phenomenological

Analysis. London: SAGE

Publication.

Storm, I. and D. Voas. (2012). The Intergenereational transmission of religious service attendance". Nordic Journal of Religion and Society, 25

(2): $131-150$ 